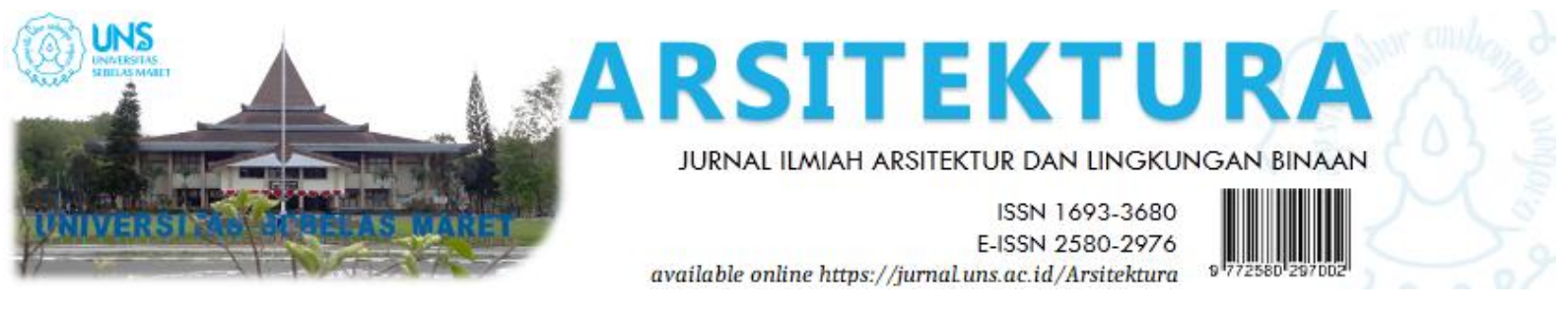

Volume 18 Issue 2 October 2020, pages:227-238

\title{
Penerapan Arsitektur Tradisional Bali pada Perancangan Teater Kesenian Kontemporer di Badung
}

\author{
Application of Traditional Balinese \\ in the Design of Theater Art in Badung
}

\author{
Yohanes Karyadi Kusliansjah ${ }^{1}$, Alan Darma Saputra ${ }^{2}$ \\ Program Studi Magister Arsitektur, Fa kultas Teknik, Universitas Ka tolik Parahyangan ${ }^{1}$ \\ karyadi@unpar.ac.id \\ Program Studi Magister Arsitektur, Fa kultas Teknik, Universitas Katolik Parahyangan ${ }^{2}$ \\ $8111801020 @$ student.unpar.ac.id
}

DOI: https://doi.org/10.20961/arst.v18i2.42994

Received: July 16,2020 Revised: Augusts 8, 2020 Accepted: August 12, 2020 Available online: October 31, 2020

\begin{abstract}
Bali is a gathering of tourist who come fromall over the country. Because of this, a mixture of cultures emerged on the island ranging from lifestyles such as clothing, language, food to architecture, so that over time Balinese architecture became faded. To prevent this, it is necessary to preserve traditional Balinese architecture by applying traditional forms of architecture to new buildings, especially the theater (as buildings that become icons of Balinese culture). The theory chosen was traditional Balinese architecture, contemporary theater provisions and neo-vernacular architecture. The method used to trace the case is descriptive qualitative by taking important aspects in neo-vernacular architecture as a meeting point between traditional Balinese architecture and neo-vernacular, then these aspects are used as a benchmark in the design transformation from what was originally a small span building to a wide span with a theater function. The study results obtained are guidelines and examples of the application of Asta Kosala-kosali in contemporary theater on spatial, roof, bodyandfoot structures of Balinese architecture and the combination of Balinese architectural tectonics in contemporary art theater. This journal has a high urgency because at present there are many functions that require wide-span buildings, so that Balinese architecture can be applied to buildings without eliminating the culture or noblevalues in it.
\end{abstract}

Keywords: Balinese Architecture;Theater; ContemporaryArts; Neo-Vernacular; Asta Kosala-Kosali.

\section{PENDAHULUAN}

Pulau Bali adalah destinasi yang terkenal di dunia, sehingga Bali menjadi pertemuan para wisatawan yang datang berlibur dari seluruh negara. Dalam beberapa tahun bahkan bali menerima pendatang dari luar pulau sebanyak lima belas juta. Karena hal tersebut, muncul percampuran budaya yang terjadi di pulau tersebut mulai dari gaya hidup seperti pakaian, bahasa, makanan sampai dengan arsitektur sebagai dampak perkembangan modernitas (Lake, Purbadi dan Harmans 2020), sehingga lama-kelamaan arsitektur Bali menjadi luntur (Sunarta dan Arida 2017) karena banyak bangunan yang berubah bentuk mengikuti fungsi yang lebih modern (Lake 2016; Salura dan Lake 2014). Hal ini diperkuat juga dengan dengan kebiasaan manusia di zaman sekarang yang lebih mementingkan fungsi dibandingkan 
bentuk bangunan (Hitchcock 1997) yang berasal dari ideologi dan kepercayaan masyarakat khususnya umat Hindu di Bali (Wardani 2018). Untuk mencegah hal ini, maka perlu dilakukan pelestarian akan arsitektur tradisional Bali dengan cara menerapkan bentuk arsitektur tradisional pada bangunan baru khususnya teater (sebagai bangunan yang menjadi ikon kebudayaan Bali) agar arsitektur di masa kini tidak tunggal rupa dan kehilangan cirinya (Lake 2014; 2015).

Untuk mempertemukan antara teknologi dengan teater kontemporer dan kebudayaan dari arsitektur tradisional Bali maka dilakukan pencampuran dalam tata ruang, bentuk dan ragam hias, hingga nilai luhur yang ada di dalam kebudayaan Bali (Wijaya 2016). Pencampuran ini dapat dilakukan salah satunya dengan menerapkan konsep bentuk bangunan Bali lama kepada teater kontemporer dengan pendekatan desain mimikri dari barang yang berhubungan dengan kebudayaan Bali (Antoniades 1990).

Proses mimikri dilakukan dalam langgam arsitektur neo-vernakular sebagai lapisan yang melingkupi perubahan fisik (struktur dan bentuk bangunan) dan non fisik (sejarah dan makna simbolis) (Arifin 2010). Tujuan penelitian ini yaitu menjadi pedoman desain khususnya penerapan arsitektur tradisional Bali pada teater kesenian yang bersifat kontemporer dan memiliki bentuk fisik yaitu bangunan bentang lebar.

Teori yang dipilih adalah arsitektur tradisional Bali, ketentuan teater kontemporer yang dan arsitektur neo-vernakular. Metoda yang digunakan untuk menelusuri kasus adalah kualitatif deskriptif dengan cara mengambil aspek-aspek penting dalam arsitektur neovernakular sebagai titik pertemuan antara arsitektur tradisional Bali dan neo-vernakular. Hasil studi yang didapat adalah pedoman dan contoh penerapan Asta Kosala-kosali pada teater kontemporer pada tata ruang, atap, badan dan kaki bangunanbercitra Bali serta perpaduan tektonika arsitektur Bali pada teater kesenian Dalam desain berupa 3 dimensi.

\section{METODE}

Metode yang digunakan di dalam penelitian ini adalah kualitatif dengan pengamatan dan penilaian kasus studi dari pandangan peneliti untuk menerapkan arsitektur tradisional Bali pada teater kontemporer.

Di dalam penelitian kualitatif, peneliti bertindak sebagai instrumen penelitiannya; sebagai instrumen penelitian, peneliti harusnya memiliki pengetahuan akan teori yang berhubungan dengan kasus, sehingga mampu bertanya, menganalisis, memotret dan mengkonstruksi keadaan sosial yang diteliti menjadi lebih jelas dan juga lebih bermakna (Sugiyono 2008).

Pendekatan yang dipilih merupakan deskriptif yang akan menafsirkan berbagai hal seperti keadaan, kegiatan dan dampak lainnya sekaligus menganalisis penelitian akan tetapi belum mencapai kesimpulan yang lebih luas (Sugiyono 2014).

Kasus penerapan arsitektur tradisional Bali pada teater kesenian di kabupaten Badung ini dipilih karena kebutuhan akan wadah bagi aktivitas seni yang berada di daerah tersebut dikutip dari RPJMD (Rencana Pembangunan Jangka Menengah) di Badung, sehingga keberadaan teater kesenian disana akan menjadi representatif yang baik untuk memperkenalkan arsitektur tradisional Bali secara lebih modern. Selain itu kebutuhan pemenuhan fasilitas ini juga tercatat dalam pengembangan nilai budaya kabupaten Badung dalam poin 14, halaman 235 dengan judul sub-bab "Parade Seni Drama Teater Sastra" sehingga memiliki tingkat urgensi yang cukup tinggi.

Secara prosedural, penelitian dibagi menjadi menjadi 3 bagian yaitu :

1. Tahap pertama adalah pengambilan aspekaspek yang ada di dalam neo-vernakular sebagai titik pertemuan di dalam mencampur antara arsitektur tradisional Bali dan teknologi teater kesenian kontemporer. 
2. Tahap kedua adala pembahasan aspek dalam bentuk pedoman desain sebagai batasan dalam penerapan desain.

3. Tahap terakhir adalah contoh aplikasi pedoman dalam desain teater kesenian kontemporer dalam langgam arsitektur neovernakular.

Kasus penerapan arsitektur tradisional Bali pada teater kesenian di kabupaten Badung ini dipilih

Pedoman akan unsur tradisional Bali dalam penelitian ini merupakan konsep bentuk tradisional Bali yang membuat mikrokosmos sebagai gambaran dari makrokosmos, sehingga masyarakat memiliki adat turun-temurun seperti penataan ruang Tri Mandala dan juga Sanga Mandala. Dari tampak bangunan terbagi 3 bagian (kepala, badan, kaki) yang sering disebut Tri Angga. Serta tektonika tradisional dan hubungannya dengan lingkungan (I Nyoman Gelebet 1985).

Kemudian pedoman tersebut lalu diterapkan dalam desain yang melingkupi aspek fisik dan non fisik seperti tata letak lokasi, bentuk dari bangunan, tampak, bahan bangunan dan konstruksi yang berarti jika elemen-elemen tersebut yang merupakan suatu respon terhadap lingkungan sekitar pada bangunan tradisional masa lalu yang ditampilkan pada bangunan modern (Nawawiy 2004).

Lingkup penelitian terletak di kabupaten Badung di Bali, alasan pemilihan dikarenakan masih barunya pusat pemerintahan tersebut, sehingga belum memiliki fasilitas secara lengkap khususnya teater kesenian. Letak yang berdekatan ini dipilih dengan harapan agar mempermudah akses apabila dilaksanakanya acara kebudayaan.

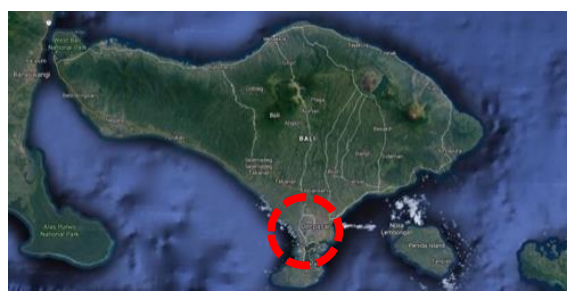

Gambar 1. Lokasi Tapak Sumber: Googlemaps, 2020.

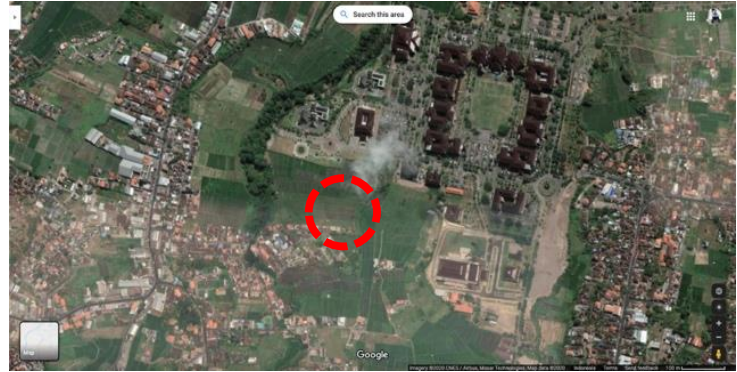

Gambar 2. Lokasi Detail Tapak Sumber: Googlemaps, 2020.

Luas lahan tapak yang dipilih adalah seluas $7.580 \mathrm{~m}^{2}$ dengan kondisi bekas ladang sawah dan berkontur. Sekitar tapak dibatasi oleh :

- Utara : Terdapat sawah dan juga kawasan

Bangunan Pemerintah Badung

-Timur : Jalan desa (jalan tanpa aspal)

-Selatan : Permukiman penduduk

-Barat : Sawah dan juga sungai

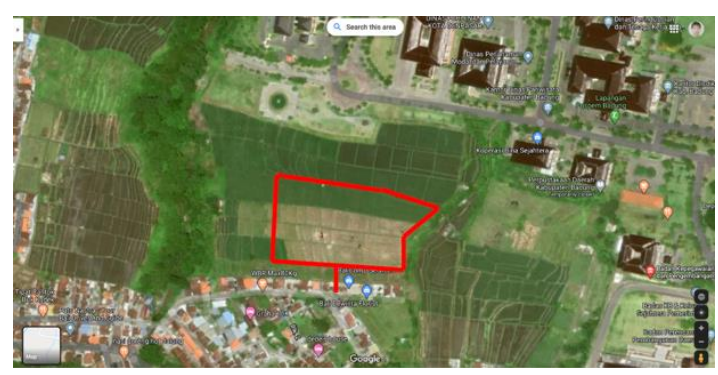

Gambar 3. Bentuk Tapak

Sumber: Googlemaps, 2020.

Sedangkan besaran teater diambil dari jumlah penduduk yang ada di Mengwi kabupaten Badung sebanyak 50.291 penduduk sehingga target teater menampung kapasitas sebanyak 500-600 kursi (Neufert 2002).

\section{HASIL DAN PEMBAHASAN}

\subsection{Penjabaran Aspek}

Pada arsiteknur neo-vernakular, didapatkan beberapa aspek yang mengacu kepada tata ruang (yang memiliki makna), sosok (bentuk), sistem (teknis dan budaya) serta lingkungan (Mentayani dan Ikaputra 2011) untuk membedah arsitektur tradisional Bali dan menerapkannya pada teater modern. 


\section{Penjabaran Aspek Tata Ruang}

Pada tata ruang di dapat beberapa ketentuan seperti arah bangunan, Tri Mandala (perbedaan ketinggian) dan juga Sanga Mandala (9 petak yang memiliki fungsi masing-masing pada pekarangan masyarakat Bali).

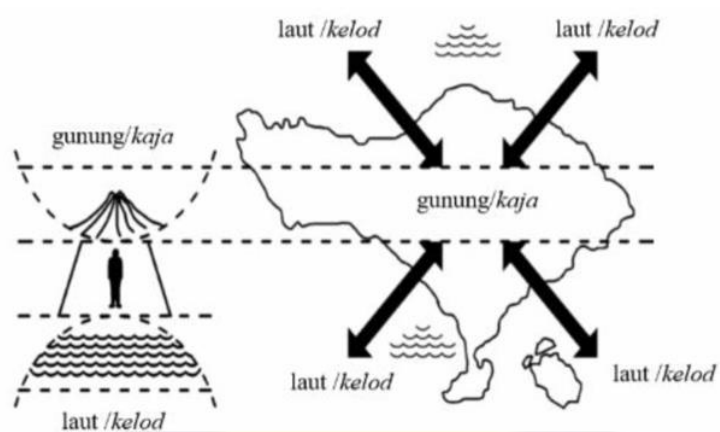

Gambar 4. Orientasi Tapak Sumber: Gusti Agung, 2012.

Orientasi pada arsitektur Bali juga dianggap penting, sehingga ruang yang punya kepentingan lebih tinggi diletakkan menghadap ke gunung, sedangkan yang kurang penting menghadap ke laut.

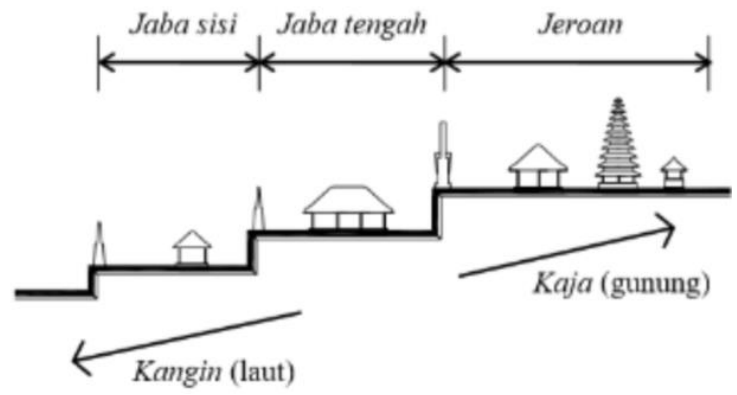

Gambar 5. Ketinggian Tata Ruang Sumber: Gusti Agung, 2012.

Ketinggian pada arsitektur Bali menjadi penting, sehingga ruang yang punya kepentingan lebih tinggi diletakkan pada dataran yang lebih tinggi dan menghadap ke arah gunung (karena gunung dianggap sakral bagi masyarakat Bali). Sedangkan pada ruang yang dianggap kurang penting terletak lebih rendah dan menghadap ke arah laut. Sehingga orientasi ruang pada arsitektur Bali berbedabeda pada setiap bagian pulau tergantung kondisi di sekitarnya.

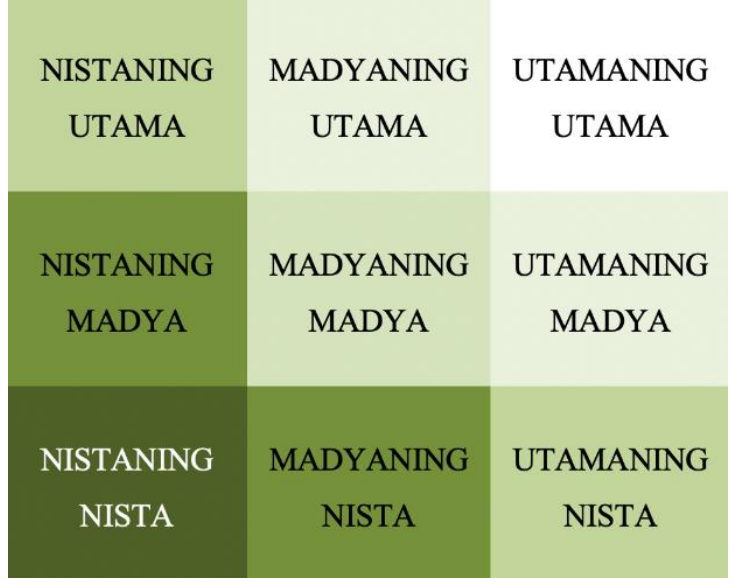

Gambar 6. Ta ta Ruang Arsitektur Tra disional Ba li Sumber: Gusti Agung, 2012.

Nistaning Nista adalah letak Candi Bentar yang berfungsi sebagai akses masuk ke Pura sehingga dapat berkembang sebagai akses masuk kendaraan maupun sirkulasi manusia ke bangunan.

Madyaning Nista adalah letak Bale Kul-kul yang berfungsi memberi informasi jika ada acara adat sehingga dapat berkembang sebagai pusat informasi bagi pendatang.

Utamaning Nista adalah paon untuk menyajikan makanan sehingga dapat berkembang sebagai dapur, kantin, kamar sepen maupun tempat servis bagi para staff.

Nistaning Madya adalah Bale Piasan untuk berhias sebelum akhirnya mereka beraktivitas sehingga dapat berkembang juga sebagai tempat persiapan maupun ruang gladi.

Madyaning Madya dapat berupa wantilan atau pelataran sehingga dapat berkembang sebagai ruang publik dalam bentuk ruang acara, taman atau teater.

Utamaning Madya dapat berupa wantilan atau pelataran sehingga dapat berkembang sebagai ruang publik dalam ruang musyawarah, ruang acara, taman.

Nistaning Utama adalah kamar sebagai tempat beristirahat sehingga dapat berkembang sebagai hotel, asrama maupun tempat beristirahat lainnya.

Madyaning Utama adalah perantara antar ruang maupun Meru sehingga dapat berkembang sebagai perpanjangan maupun perantara ruang lainnya.

Utamaning Utama adalah Padmasana yang bersifat paten sehingga tidak dapat berubah (untuk di pulau Bali). 
Di pedoman tata ruang didapatkan kesimpulan bahwa penerapan arsitektur Bali pada teater tetap menggunakan ketinggian dan orientasi pada ruang yang dianggap penting, khususnya tempat beribadah. Sedangkan pada fungsinya dapat di rubah dengan fungsi baru yang mirip.

\section{Penjabaran Aspek Sosok}

Sosok pada arsitektur tradisional Bali terbagi menjadi 3 bagian bangunan yang harus dipertahankan yaitu bentuk tradisional atap (simbol kepala), pelingkup (simbol badan) dan bataran (simbol kaki) seperti berikut ini :

Atap
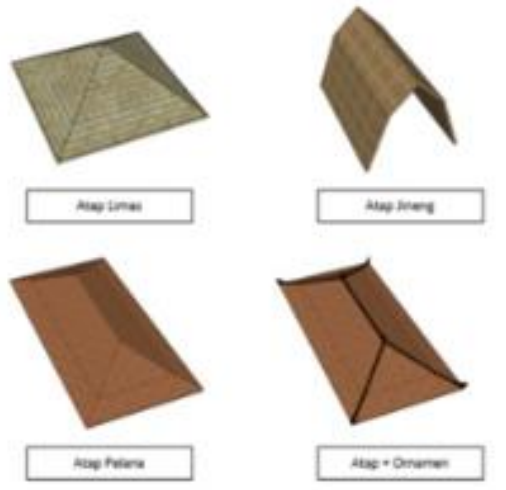

Pelingkup
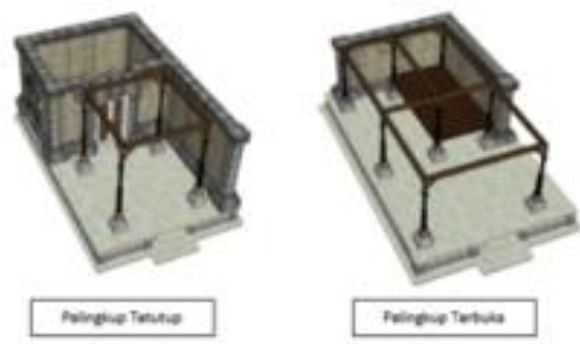

Bataran
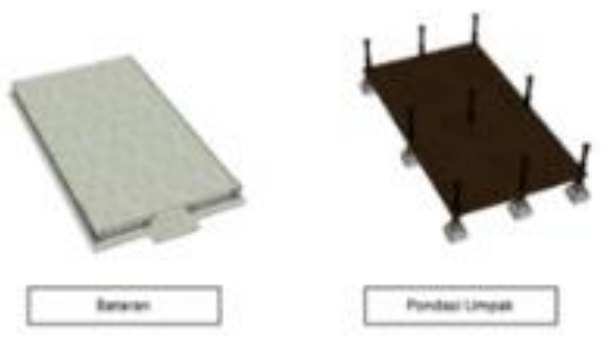

Gambar 7. Tiga Sosok Bangunan Bali
Bentuk diatas merupakan kewajiban di daerah Bali, akan tetapi dapat dimodifikasi agar menyesuaikan dengan fungsi tertentu dengan skala bentang lebar.

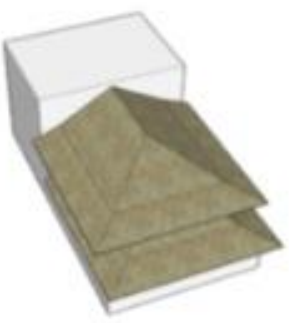

Gambar 8. Modifikasi Atap Geser Bali

Atap Bali untuk bentang lebar dapat dipecah menjadi beberapa bagian dengan cara menggeser atap yang disatukan sehingga menaungi bagian yang berbeda-beda akan tetapi tetap menjaga siluet atap tradisional Bali.

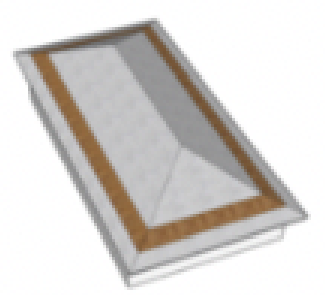

Gambar 9. Modifikasi Material Atap Bali

Atap Bali dapat dipertahankan bentuknya, akan tetapi dengan perubahan konstruksi maupun material yang digunakan sehingga ketentuan Bali tetap dapat dipatuhi.

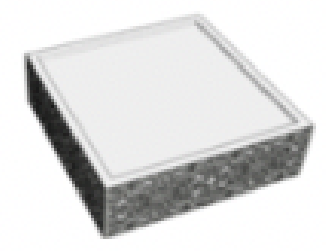

Gambar 10. Modifikasi Dinding Tertutup Bali

Untuk pelingkup Bali yang pertama adalah bersifat tertutup dapat menggunakan ukiranukiran maupun simbol Bali sehingga suasana bali tercermin pada dinding. Secara tradisional dinding tertutup ini biasanya terletak pada tempat istirahat dan dapur. 


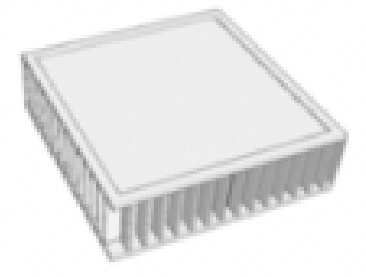

\section{Gambar 11. Modifikasi Dinding Terbuka Bali}

Untuk pelingkup Bali yang terbuka dapat tetap dipertahankan akan tetapi pada bagian dalamnya harus kedap suara untuk keperluan teater. Secara tradisional biasanya terletak pada ruang berkumpul, penerima tamu maupun ruang untuk menampilkan kesenian (nyanyian, drama dan sendratari).

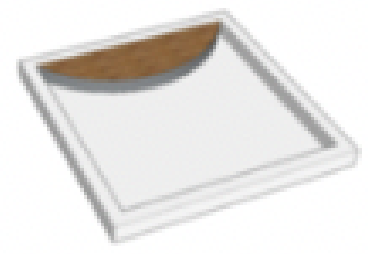

Gambar 12. Modifikasi Bagian Bawah Bataran

Bataran Bali dapat dimodikasi sebagai tempat penyimpanan maupun gudang sebagai pemenuhan kebutuhan peralatan panggung.

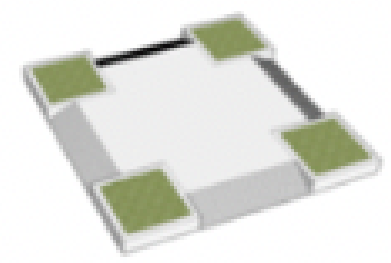

Gambar 13. Modifikasi Bagian Atas Bataran

Bataran Bali dapat dimodikasi dan memiliki bentuk dan fungsi yang beragam asalkan memisahkan bangunan dari tanah langsung.

Sosok Bali didapat kesimpulan bentuk pada tiga bagian bangunan harus dijaga konsepnya yaitu kepala (berbentuk tradisional), badan (tertutup dan terbuka) dan kaki (harus memiliki jarak antara bangunan dan tanah) selain ketentuan tersebut dapat di rubah sesuai kebutuhan.

\section{Penjabaran Aspek Sistem}

Arsitektur Tradisional Bali menganut beberapa sistem tektonika (ketukangan) pada pembuatan bangunanya seperti bagaimana menimbulkan kejujuran material yang digunakan dalam rangka atap, keterbukaan dinding, kolom, bataran dan juga ukiran yang menghadirkan suasana Bali. Berikut adalah penjelasannya :

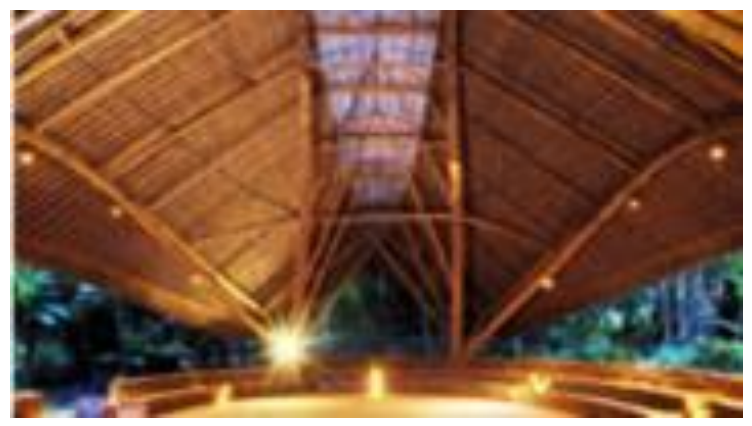

Gambar 14. Modifikasi Plafon Bali

Penggunaan kayu imitasi bisa mereduksi kerusakan alam dan meningkatkan potensi dari materialnya, serta penggunaan kaca untuk menampilkan rangka bagian dalamnya.

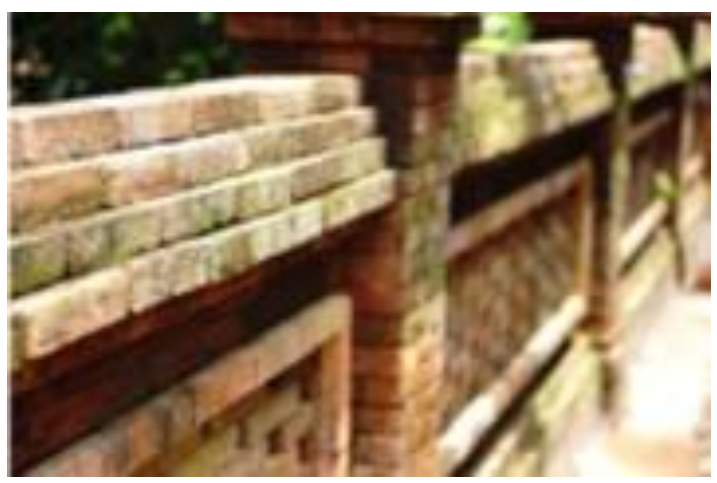

Gambar 15. Modifikasi Dinding Bali

Penggunaan beton dan insulasi seperti rockwool dapat menginsulasi suara yang dihasilkan teater secara lebih baik sedangkan bagian luar auditorium dapat tetap mempertahankan keterbukaan yang ada meskipun materialnya berbeda. 


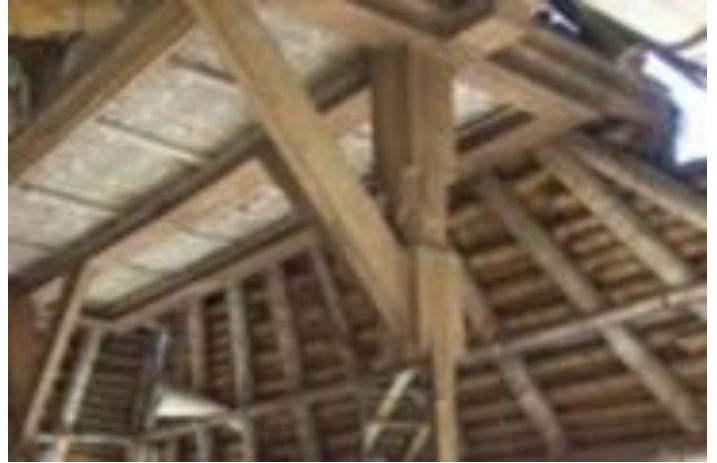

Gambar 16. Modifikasi Struktur Bali

Penggunaan kayu pada bangunan Bali umumnya memiliki peruntukkan untuk bangunan rendah, sehingga potensi untuk menggunakan kayu komposit dapat dilakukan dengan memberi warna coklat untuk mewujudkan suasana kayu.

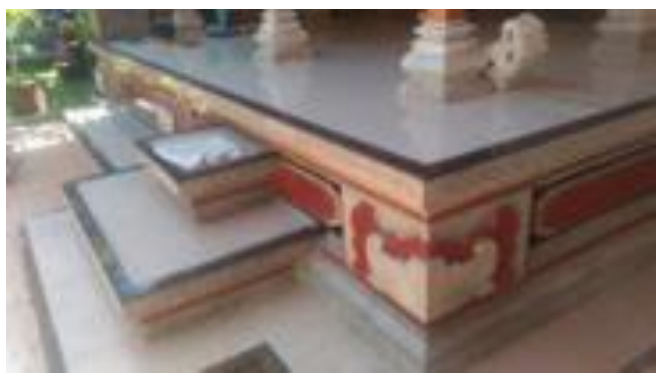

Gambar 17. Modifikasi Bataran la innya

Penggunaan material pada bataran bisa dimodifikasi misalnya panggung untuk daerah banjir, pilotis untuk fungsi lain dsb, asalkan memiliki tujuan untuk memisahkan bangunan dan tanah yang dipijak secara langsung.

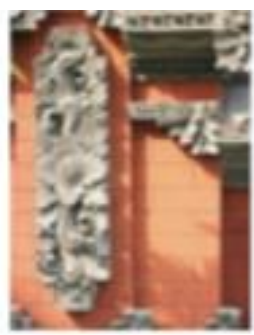

Gambar 18. Modifikasi Ukiran Bali

Penggunaan batu sebagai ukiran akan mengurangi penggunaan material alam dan mempercepat pengerjaan, sehingga bisa di rubah bahan seperti plastik, papan semen dan lainnya.

Pada pedoman sistem didapatkan kesimpulan bahwa penerapan arsitektur Bali pada teater akan memperkuat suasana Bali dengan permainan warna, keterbukaan, bentuk dan sebagainya, hal ini dapat terwujud karena pada masa kini tersedia banyak pilihan material untuk meningkatkan potensinya menjadi lebih baik.

\section{Penjabaran Aspek Lingkungan}

Sifat kelokalan bangunar $\cdots n n$ h hrm.ıbungan dengan lingkungan pada c .... disional Bali diambil dari sumber daya alam yang ada di sekitarnya, akan pada masa kini dapat ditingkatkan potensinya (seperti ketahanan pada api, kekuatan dan peredam bising) dengan pemilihan material pengganti dengan cara tetap mempertahankan nilai lokal dan suasana Bali.

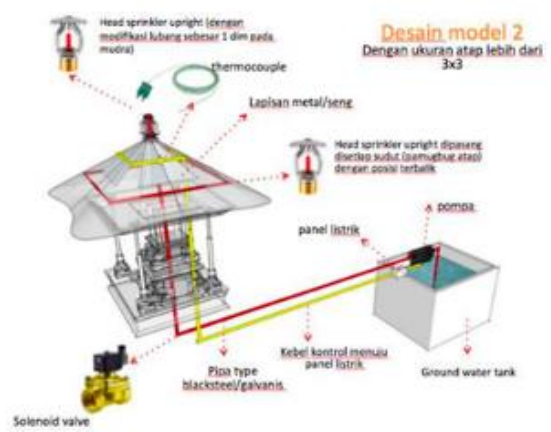

Gambar 19. Modifikasi Keamanan Atap Bali Sumber: sa martaarsitek tur.unud.ac.id

Pada bangunan Bali, material alam ditonjolkan pada segala bagian bangunan. Akan tetapi lemah terhadap api sehingga perlu dilengkapi dengan termocouple yang disambung ke sprinkler untuk mencegah kebakaran.

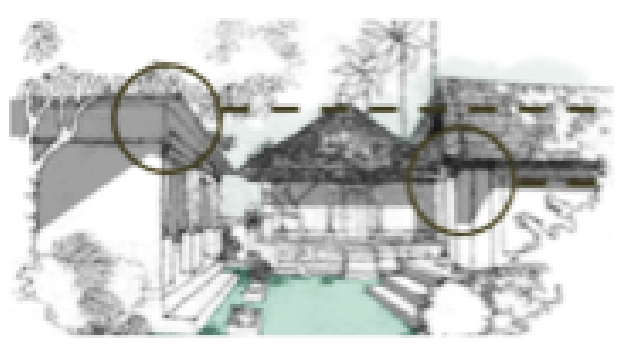

Gambar 20. Kanopi Atap Bali Sumber: sa martaarsitektur.unud.ac.id

Kanopi juga sering digunakan pada arsitektur Bali, akan tetapi panjangnya terbatas 1-2 meter karena menggunakan bahan kayu, untuk memperluas potensinya dapat menggunakan 
bahan prefabrikasi seperti besi dan baja agar lebih kuat dan lebar.

Penggunaan pondasi Bali sekaligus digunakan untuk bataran sehingga akan kuat jika terjadi gempa, pondasi dapat diganti jenis dengan bentuk yang mirip seperti pondasi pola rakit dengan material beragam.

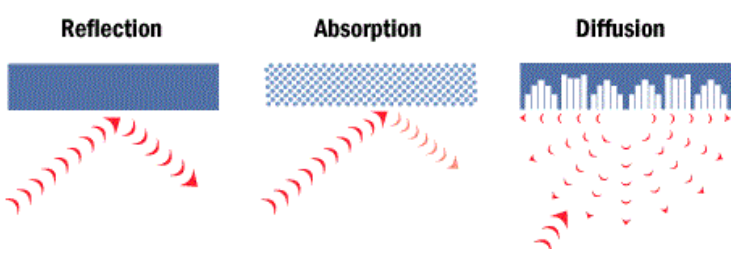

Gambar 21. Sifat Pemantulan Suara Sumber: cruchfield.com

Pemantul peredam dan penyebar pada bangunan Bali hanya mengikuti bentuk bangunan yang sudah ada, sehingga perlu ditambahkan pada bagian auditoriumnya, sedangkan pada bagian luarnya cenderung bebas.

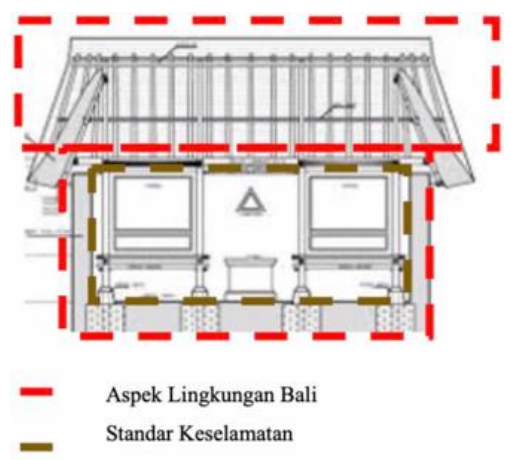

Gambar 22. Lingkup Perlindungan Bangunan

Lingkup perlindungan dari alam sebenarnya dapat dibedakan dimana Bali berada di bagian luar yang berhubungan langsung dengan alam, sedangkan teater berada di bagian dalam yang berhubungan dengan penggunanya.

Pedoman lingkungan didapatkan kesimpulan bahwa penerapan arsitektur Bali pada teater bersifat berdampingan dilihat dari aspek lingkungan Bali yang menjawab kondisi alam secara langsung dari luar, sedangkan pada teater lebih menjawab alam dengan mengendalikan perilaku pengguna di dalamnya.

\subsection{Penerapan Desain}

Penerapan dalam desain bangunan pada tapak menggunakan perumpamaan bingkai arsitektur yang menerapkan siluet perkampungan Bali pada sekitarnya, sedangkan pada bagian tengah (teater) lebih menonjolkan sifat internasional dengan menggunakan langgam neo-vernakular.

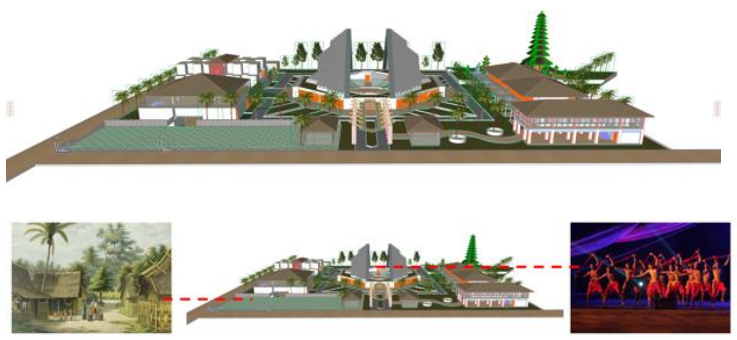

Gambar 23. Penampakan Desain

Kemudian penerapan mimikri pada desain diambil dari bentuk mahkota penari Bali yang merupakan ikon dari kesenian Bali. Bentuk mahkota ini diambil dan diterapkan sebagai atap Teater sebagai mahkota teater yang menghiasi pada bagian atasnya dan juga menjadi simbol bagi teater yang merupakan wadah bagi kesenian tradisional Bali.
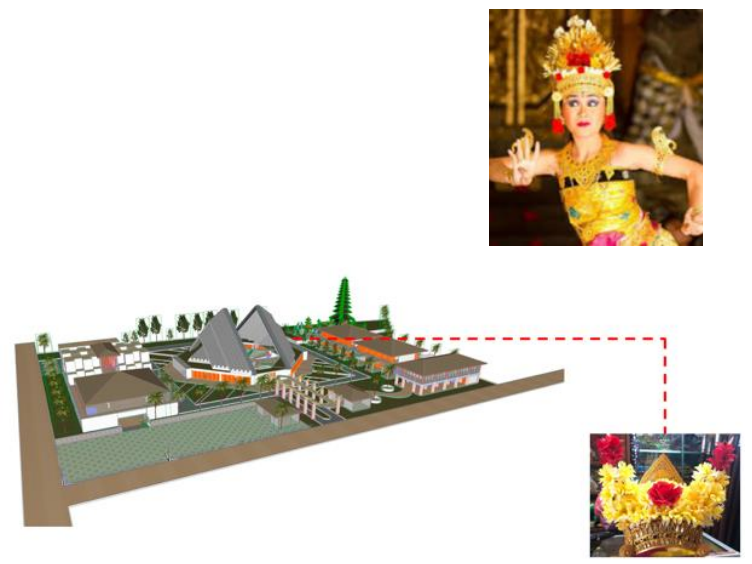

Gambar 24. Objek Mimikri Desa in

\section{Penerapan Tata Ruang}

Penerapan tata ruang pada teater menggunakan fungsi yang berdekatan karakternya (mirip) kecuali pada akses masuk, ruang berkumpul dan padmasana pada bagian ujung tapak. Penerapan tata ruang antara lain seperti pada tabel 1. 
Tabel 1. Penerapan Aspek Tata Ruang Ba li

\begin{tabular}{|c|c|}
\hline Fungsi Lama & Fungsi Baru \\
\hline Candi Bentar (Akses) & Akses dan Parkir \\
\hline Bale Kul-kul & Pusat Informasi \\
\hline Paon (Dapur) & $\longrightarrow$ Loka Karya dan servis \\
\hline $\begin{array}{c}\text { Bale Piasan } \\
\text { (Tempat Berhias) }\end{array}$ & Ruang Latihan \\
\hline Lapangan/wantilan & Teater Tertutup \\
\hline $\begin{array}{c}\text { Bale Dangin } \\
\text { (Tempat Tamu) }\end{array}$ & Komersial \\
\hline $\begin{array}{c}\text { Uma Meten } \\
\text { (Tempat Tinggal) }\end{array}$ & Asrama \\
\hline Perantara & Teater Terbuka \\
\hline $\begin{array}{l}\text { Padmasana dan meru } \\
\text { (Tempat Beribadah) }\end{array}$ & $\longrightarrow$ Padmasana dan Meru \\
\hline
\end{tabular}

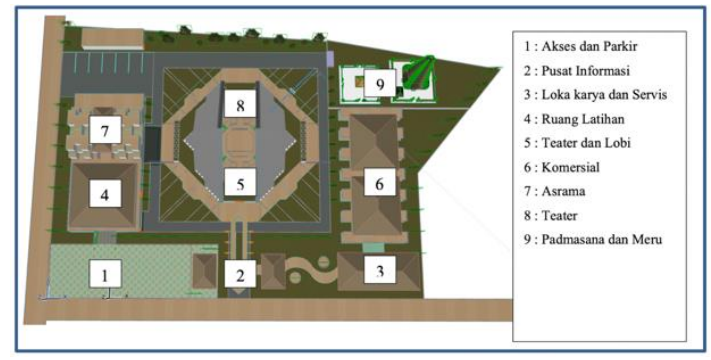

Gambar 26. Penerapan Aspek Ta ta Ruang Bali

\section{Penerapan Sosok}

Pada teater sosok bali dibedakan menjadi 3 bagian pada atap (kepala), pelingkup (badan dan pondasi (kaki) seperti berikut ini :

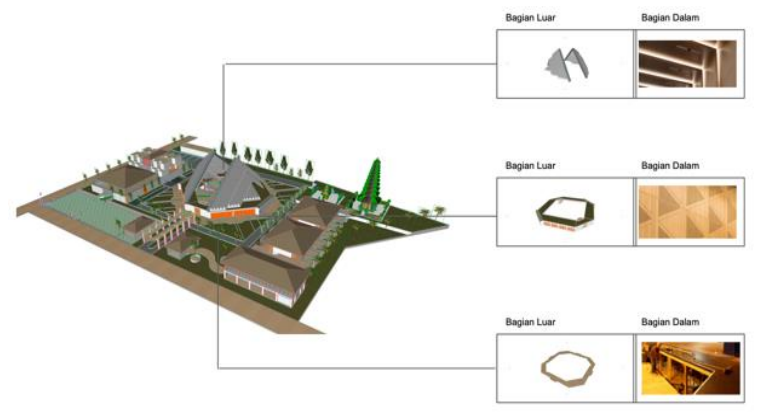

Gambar 27. Penerapan Aspek Sosok Bali
- Atap

Atap pada teater dibuat terbagi menjadi tiga bagian sesuai dengan tribun pada bagian bawahnya sehingga tidak menampung luasan yang begitu besar dan tetap mempertahankan bentuk atap tradisional, sehingga arsitektur Bali dapat terwujud dalam bangunan bentang lebar khususnya teater kontemporer

\section{- Pelingkup}

Bagian dinding dibuat terbuka dengan cara penerapan pola kain bali pada dindingnya yang menambah permainan cahaya dan bayangan pada malam hari, akan tetapi pada bagian dalamnya tetap dibuat kedap suara sehingga kenyamanan teater tidak terganggu

\section{- Bataran}

Sedangkan bagian bataran teater memiliki fungsi untuk gudang yang digunakan sebagai tempat penyimpanan peralatan panggung yang dibutuhkan selama pertunjukan dan juga kebutuhan utilitas bangunan

\section{Sistem}

Pemilihan konstruksi dan material pengganti pada teater perlu dilakukan sebagai upaya untuk meningkatkan potensi material yang ada dalam mewadahi bangunan teater akan tetapi tetap memperhatikan suasana material alam yang ada di bangunan tradisional Bali, antara lain :

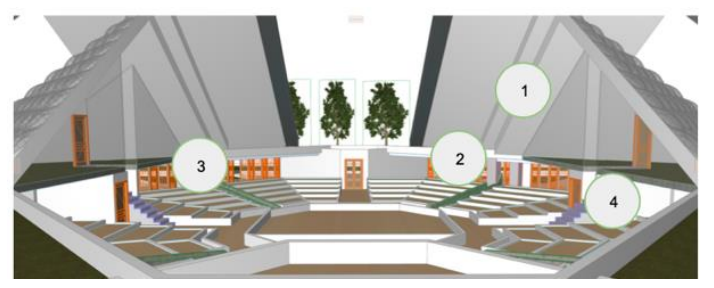

Gambar 28. Penerapan Aspek Sistem Bali

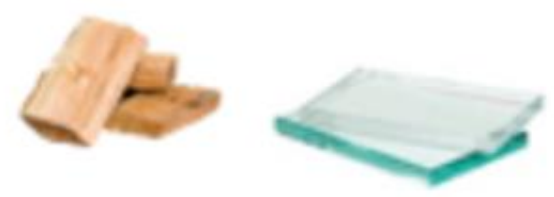

Gambar 29. Material Atap Teater

Penggunaan baja atap dapat dimodifikasi dengan pengaplikasian material komposit sehingga menyerupai kayu, selain itu 
penggunaan kaca dapat dipilih jika ingin memperlihatkan rangka atapnya.
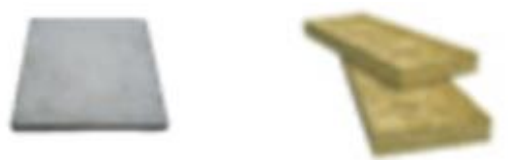

Gambar 30. MaterialDinding Teater

Material yang digunakan pada dinding auditorium berupa beton yang dilapisi panel, stc pada bagian samping. Sedangkan pada bagian belakang dapat menggunakan karpet dan rockwool sebagai peredam.
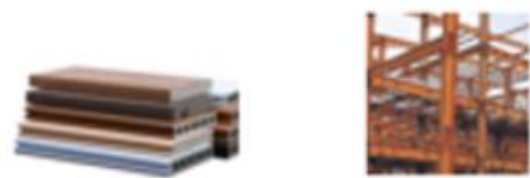

Gambar 31. Material Struktur Teater

Struktur pada bagian belakang menggunakan kolom beton, sedangkan pada bagian depan menyambung pada shearwall sehingga penonton dapat menikmati pertunjukan tanpa halangan.
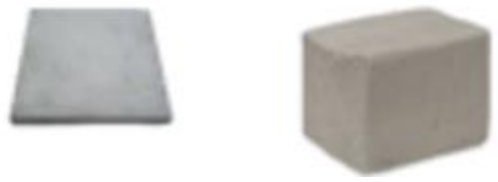

Gambar 32. Material Bataran Teater

Pada bataran menggunakan material beton untuk membatasi air kolam untuk masuk ke bangunan.

\section{Lingkungan}

Pada bagian dalam teater dapat menggunakan material pemantul, penyebar dan peredam untuk mengatasi suara yang ditimbulkan oleh teater, sedangkan pada bagian luar teater dibuat taman di sekitarnya dan juga pemberian vegetasi tambahan sebagai peredam suara yang merambat keluar.

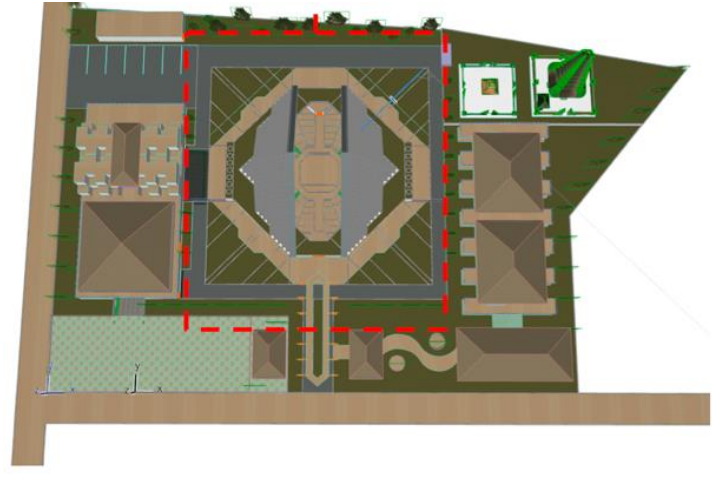

Gambar 33. Penerapan Aspek Lingkungan Bali

Material alam seperti ijuk dan sirap tetap dapat diaplikasikan pada atap teater, akan tetapi harus dibantu dengan penambahan teknologi di dalamnya misalkan pada bagian dalam dengan bantuan sprinkler dan alarmm sedangkan pada bagian luar dengan pemasangan termocouple, sprinkler dan lapisan metal pada bagian bawahnya, sehingga air akan dipadamkan jika terjadi kebakaran pada bagian atap.
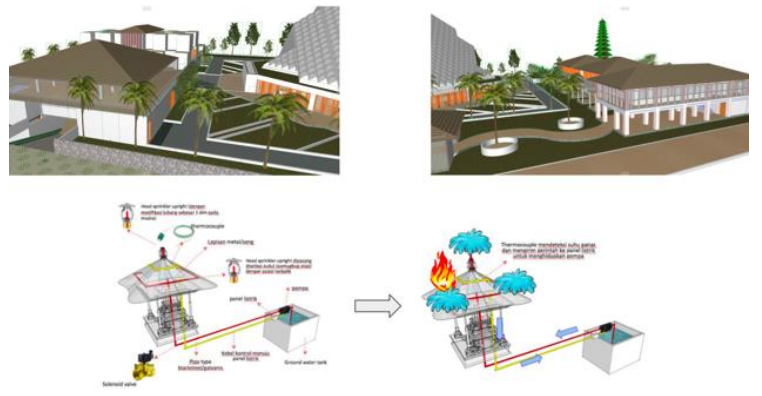

Gambar 34. Penerapan Aspek Lingkungan Bali pada Atap

\section{KESIMPULAN}

Kesimpulan pada penelitian ini adalah untuk menerapkan Arsitektur Tradisional Bali pada teater maka dibutuhkan 4 aspek yaitu sebagai berikut :

\section{Tata Ruang}

Penataan ruang dari hasil analisa yang didapat menunjukkan bahwa pada arsitektur Tradisional Bali sangat mementingkan penataannya karena berhubungan dengan kepercayaan masyarakat setempat dan juga menjadi jawaban dari keadaan lingkungan yang ada disekitarnya. Sedangkan pada teater lebih mengutamakan hubungan antar ruang di dalamnya karena berhubungan dengan sistem kerja teater tersebut sehingga dapat memasukkan fungsi tersebut kedalam petak pada tata ruang Bali. 
Fungsi yang ada juga dapat berubah mengikuti kebutuhan asalkan memiliki sifat yang hampir serupa.

\section{Sosok}

Pemilihan sosok pada Bali diwakili dengan bentuk dari pada tiga bagian bangunan yang ada seperti kepala (atap berbentuk tradisional), badan (dinding pelingkup yang tertutup dan terbuka) dan kaki (pondasi yang harus memiliki jarak antara bangunan dan tanah) yang cenderung unik pada daerah Bali. Sedangkan pada teater sosok yang dipertahankan hanya pada bagian auditoriumnya yang berhubungan dengan kenyamanan yang dinikmati oleh pengunjung saat menikmati pertunjukkan. Sehingga sosok yang dituntut pada masing-masing variabel berbeda (Arsitektur Bali pada pelingkupnya dan teater pada bagian dalamnya).

\section{Sistem}

Pada Arsitektur Tradisional Bali sistem konstruksi pada bangunannya dapat berubah sesuai dengan konsep Desa, Kala, Patra(tergantung tempat, waktu dan kondisinya) sehingga bersifat tidak pasti dan juga mendominasi bagian kulit bangunan yang langsung berhubungan dengan alam. Berbeda dengan sistem yang ada di dalam teater yang lebih kaku terutama pada materialnya, sehingga penerapannya dapat menggunakan konstruksi Bali dengan material yang ramah lingkungan dan aman untuk teater serta pengaplikasiannya indoor serta meningkatkan potensi dari material tersebut.

\section{Lingkungan}

Lingkungan pada arsitektur Bali lebih bersifat pasif serta berada diluar bangunan dan langsung berhubungan dengan alam seperti aliran angin yang natural ataupun sirkulasi yang cukup terbuka. Sedangkan pada teater cenderung menganut ke peraturan yang ada untuk bangunan umum. Sehingga perlu adanya penggabungan agar sesuai dengan konteks bali maupun teater seperti penggunaan material tahan api, pemakaian gas pada pemadaman kebakaran maupun sprinkler yang bersifat otomatis. Sehingga kedua perlindungan ini dapat saling berdampingan dalam menjamin keselamatan pengguna dari luar maupun dalam bangunan.

\section{REFERENSI}

Agung, Gusti. (2012). Konsepsi Tri Mandala Dalam Arsitektur Bali. Universitas Udayana, Bali.

Antoniades, Anthony C. (1990). Poetics of Arhitecture. McGraw-Hill Book Co, London.

Appleton, Ian. (2008). Buildings for the Performing Arts. The Architectural Press Ltd, London.

Arifin. (2010). Evaluasi Pembelajaran. Bandung: Remaja Rosdakarya.

Association of British Theatre Technician. (1972). Theatre Planning. Wiley, United States.

De Chiara, Joseph. (1973). Times Saver Standard for Building Types. McGrawHill Book Co, London.

Gelebet, I Nyoman. (1985). Arsitektur Tradisional Daerah Bali, Indonesia: Departemen Pendidikan dan Kebudayaan Proyek Inventarisasi dan Dokumentasi Kebudayaan Daerah.

Hitchcock, Henry-Russell \& Johnson, Philip. (1997). The International Style. W.W. Norton \& Company, United States of America.

Lake, Reginaldo Christophori. 2014. “Konsep Ruang Dalam dan Ruang Luar Arsitektur Tradisional Suku Atoni di Kampung Tamkesi di Pulau Timor." E-Journal Graduate Unpar 1 (2).

Lake, Reginaldo Christophori, Yohanes Djarot Purbadi, dan Herman Florianus Harmans. 2020. "Identification and Orientation on Spatial Arrangement of Wajo Traditional Village, Keo Tengah, Nagekeo Regency." Local Wisdom : Jurnal Ilmiah Kajian Kearifan Lokal 12 (1).

Nawawiy, M (2004). Raibnya Para Dewa. Universitas Sumatera Utara.

Peraturan Badan Standarisasi Nasional tahun 2000. SNI-03-1746-2000.

Raka, Anak Agung Gede. (2019). Konsep Desain Mitigasi Bencana Kebakaran Pada Pura Beratap Ijuk. Jurnal Arsitektur Zonasi.

Rapoport, Amos. (1977). Human Aspect of Urban Form. International School Oxford: Pergamon. 
Rapoport, Amos. (1969). House Form and Culture. Prentice Hall International Inc., London.

Salura, Purnama, dan Reginaldo Christophori Lake. 2014. "The architectural language of inner and outer space as observed among the Atoni tribe in the Tamkesi kampong on Timor Island." International Journal of Academic Research 6 (3).

Soelaiman, Tubagus M. Aziz. (2010). BSD Performing Arts Centre. Institut Teknologi Bandung, Bandung.

Sugiyono. 2008. Metode Penelitian Kuatintatif, Kualitatif Dan R\&D. Alfabeta. https://doi.org/2008.

- 2014. 'Teknik Pengumpulan Data'.MetodePenelitian Kuantitatif, Kualitatif Dan R\&D.

Sunarta, Nyoman, and Nyoman Sukma Arida. 2017. Pariwisata Berkelanjutan. I. Bali: Cakra Press.

Wijaya, I Kadek Merta. 2016. “Telaah Arsitektur Vernakular Pada Artikel: The Balinese. 